\title{
Routine preoperative thoracic angiography or just follow the gut feeling?
} \author{
and Michele Di Mauro, $\mathrm{MD}, \mathrm{PhD}^{\mathrm{c}}$ \\ From ${ }^{\mathrm{a} C}$ Cardiac Surgery, Pope John Paul II Foundation, Campobasso; ${ }^{\mathrm{b}}$ Cardiac Surgery, SS Annunziata Hospital, \\ Chieti; and ${ }^{\mathrm{c} C a r d i o l o g y}$ and Cardiac Surgery, API Madonna Del Ponte, Lanciano, Italy. \\ Disclosures: Authors have nothing to disclose with regard to commercial support. \\ Received for publication Sept 14, 2017; accepted for publication Sept 15, 2017; available ahead of print Oct 15 , \\ 2017. \\ Address for reprints: Antonio M. Calafiore, MD, Cardiac Surgery, Pope John Paul II Foundation, Campobasso, \\ Italy (E-mail: am.calafiore@gmail.com). \\ J Thorac Cardiovasc Surg 2018;155:e31-2 \\ $0022-5223 / \$ 36.00$ \\ Copyright (C) 2017 by The American Association for Thoracic Surgery \\ https://doi.org/10.1016/j.jtcvs.2017.09.084
}

Antonio M. Calafiore, MD, ${ }^{a}$ Carlo De Filippo, MD, ${ }^{a}$ Massimiliano Foschi, MD, ${ }^{b}$ Fabrizio Tancredi, MD, ${ }^{b}$
The rare case reported by Mashhour and coworkers, ${ }^{1}$ besides describing a collateral vascular pathway never reported so far, emphasizes in particular the need for preoperative evaluation of the thoracic arteries, which represent, as we well know, adding value for myocardial surgical revascularization both in terms of survival and event-free survival. ${ }^{2,3}$ This opens a never-ending debate: Is routine angiography of the left internal thoracic artery (LITA) necessary or not?

Patel and colleagues ${ }^{4}$ reported the results of preoperative angiographic evaluation of the LITA in 101 patients; of the LITAs, $48.5 \%$ showed lateral costal branches with diameters greater than $1.5 \mathrm{~mm}$. The incidence of significant left vertebral disease and proximal subclavian disease was $37.6 \%$ and $5 \%$, respectively. However, the authors conclude that asymptomatic subclavian artery disease and the presence of lateral costal branches preoperatively did not correlate with post-coronary artery bypass grafting ischemia in the left anterior descending territory.

In 1999, our group ${ }^{5}$ reported the results of an angiographic study to evaluate postoperatively the anatomy of the harvested LITA. A common origin with other branches of the subclavian artery was present in 99 (33\%) of 300 enrolled patients; the persistence of a lateral costal branch was rare (32 cases, 10\%). A total of 35 branches $(12 \%)$ were $1 \mathrm{~mm}$ or more. We concluded that a common origin with other branches of the subclavian artery and the persistence of the lateral costal branch are common aspects in the angiographic anatomy of the grafted LITA. Moreover, new branches, sometimes wider than $1 \mathrm{~mm}$, develop with time.

In 1992, Feit and colleagues ${ }^{6}$ found significant features in $15 \%$ of 130 LITAs evaluated preoperatively, suggesting that preoperative evaluation of LITA should be a part of diagnostic angiography.

Today, it would be impossible to submit patients to a routine preoperative double thoracic angiographic study if they are selected for coronary artery bypass grafting, because the number of both diagnostic and interventional

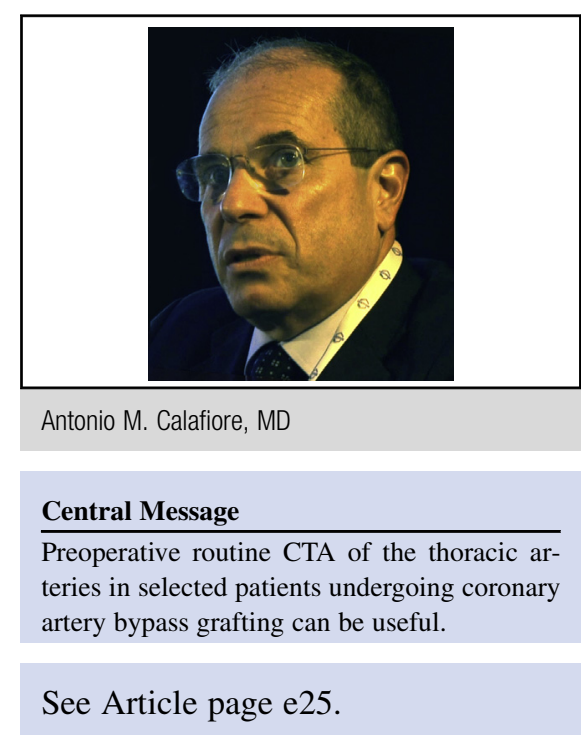

procedures, either elective or emergency, increases exponentially. In addition, selective angiography of a vessel sized $2.5 \mathrm{~mm}(1.5-3.5 \mathrm{~mm})^{7}$ is invasive and could cause subclinical lesions of the arteries, which would subsequently hamper graft functioning. In this case report, the surgeon followed the gut feeling, given the uncommon size of the LITA $(8 \mathrm{~mm})$, thus preferring a revascularization with saphenous veins. A possible compromise might be just that suggested in the authors' conclusions, which in our opinion, represent the strength of this case report: the use of a noninvasive method such as computed tomography angiography (CTA), which allows a better spatial visualization of the thoracic circulation and any collateral pathway to be made in selected patients, such as patients with vascular disease. Karaman and colleagues ${ }^{7}$ used CTA to visualize 328 thoracic arteries (164 left and 164 right), concluding that CTA provides a precise and detailed evaluation of internal thoracic arteries with anatomic features and variations.

\section{References}

1. Mashhour A, Easo J, Thabet A, Weymann A. The left internal mammary artery supplying major part of the gastrointestinal tract. J Thoracic Cardiovasc Surg. 2018; $155: \mathrm{e} 25-7$.

2. Loop FD, Lytle BW, Cosgrove DM, Stewart RW, Goormastic M, Williams GW et al. Influence of the internal-mammary-artery graft on 10-year survival and other cardiac events. N Engl J Med. 1986;314:1-6.

3. Buttar SN, Yan TD, Taggart DP, Tian DH. Long-term and short-term outcomes of using bilateral internal mammary artery grafting versus left internal mammary artery grafting: a meta-analysis. Heart. 2017;103:1419-26. 
4. Patel P, Shammas NW, Kapalis MJ, Dippel EJ, Lemke J, Harb C. Routine visualization of the left internal mammary artery before bypass surgery: is it necessary? $J$ Invasive Cardiol. 2005;17:479-81.

5. Calafiore AM, Contini M, Iacò AL, Maddestra N, Paloscia L, Iovino T, et al. Angiographic anatomy of the grafted left internal mammary artery. Ann Thorac Surg. 1999;68:1636-9.
6. Feit A, Reddy CV, Cowley C, Ibrahim B, Zisbrod Z. Internal mammary artery angiography should be a routine component of diagnostic coronary angiography. Cathet Cardiovasc Diagn. 1992;25:85-90.

7. Karaman B, Battal B, Bozkurt Y, Bozlar U, Demirkol S, Sahin MA, et al. The anatomic evaluation of the internal mammary artery using multidetector CT angiography. Diagn Interv Radiol. 2012;18:215-20. 